\title{
On Being Religious: Will Religiosity Change Our Perceptions of Pleasure in Reckless Behavior?
}

\author{
Pauline Christianti \\ Faculty of Psychology \\ Universitas Pelita Harapan \\ paulinechristianti@gmail.com
}

\author{
Karel Karsten Himawan \\ Faculty of Psychology \\ Universitas Pelita Harapan \\ karel.karsten@uph.edu
}

\author{
Yonathan Aditya \\ Faculty of Psychology \\ Universitas Pelita Harapan \\ yonathan.aditya@uph.edu
}

\begin{abstract}
Pleasure takes part as an underlying motivation in decision-making activities, including when committing conventional and reckless behaviors. Whereas previous studies have confirmed that individuals with a higher level of religiosity commit less reckless behaviors, little attention is given to further identify their pleasure perceptions toward performing such actions. This study was intended to fill the gap by demonstrating if a higher level of religiosity among emerging adults would change perceptions of pleasure, which in turns reduce the likelihood of performing reckless behavior. An online survey, participated by $44 \mathrm{I}$ emerging adults $\left(M_{\text {age }}=20.69 ; S D=1.71\right)$ living in Jakarta and Tangerang were conducted. The survey found that there exists a negative influence of religiosity towards the perception of pleasure in emerging adults' reckless behavior. This study suggests that in an attempt to reduce reckless behavior, practitioners could use indirect religious approaches, including adopting religious morality, providing a supportive community, and practicing relaxing rituals.
\end{abstract}

Keywords: Religiosity, perception of pleasure, reckless behavior, emerging adults, Indonesia.

Received 12 March 2019/Accepted I5 May 2019 @JEHCP All rights reserved

\section{Introduction}

Action is inevitable in life. Each individual has a choice to do or not do, but typically there is a reason behind every action, or what we usually call it as a motivation. Pleasure takes an important part as an underlying motivation for decisions and behavior (Biswas-Diener, Linley, Dovey, Malthy, Hurling, Wilkinson, \& Lyubchi, 2015). As a positive affect, pleasure functions in regulating the flow of behavior (Carver, 2003). Pleasure itself can be derived from certain conventional or reckless behaviors.

Some individuals engage in prosocial behaviors as it benefits themselves in terms of egoistic desire to regulate personal distress as they help others (Rucci, Allen, \& Zelenski, 2018), which thus resulting in them feeling better. In a study on motives behind volunteering, it was 
found that volunteering produces pleasure, both as an underlying motivation (Caissie \& Halpenny, 2003) and a reward (Dekker \& Halman, 2003). There are other activities, such as gaming, painting, or even skydiving, that people engage merely for the sake of getting pleasurable feelings; such force is also known as intrinsic motivation(Crow \& Small, 20 I I).

Whereas pleasures created through being engaged in the prosocial behaviors are personally and socially functionals, it becomes a concern if what brings pleasure to specific individuals are activities that have physical, psychological, and legal risks, or as Arnett (1998) termed it as reckless behavior. Arnett (1998) have found reckless behavior to be prominent among emerging adults (18-25 years old).

Particularly in Indonesia, reckless behavior raises concerns as data showed that the incidents were rising and manifested in many forms, namely drug consumption, drag racing, heavy smoking, and sexual activities (Wahid, 20I5; Yusuf, 2015). A survey has also shown a rise of cigarette consumption in Indonesia for up to 20 percent each year with the majority (70 percent) of smokers aged 16-25 ("70\% of Indonesian Smokers...," 2015). Moreover, the percentage of people infected with the Human Immunodeficiency Virus (HIV) caused by unprotected sex climbed from 38 percent to 40 percent (Rahadian, 20I4).

Whilst many studies have confirmed the influence of religiosity on reducing reckless behavior (Abar, Carter, \& Winsler, 2008; Bjarnason, Thorlindsson, Sigfusdottir, \& Welch, 2005; Cochran \& Beeghley, 1991; Hair, Moore, \& Kuhfeld, 2009), exploring such a relationship in the Indonesian context would be of a particular interest. Not only that reckless behaviors among Indonesian emerging adults are increasing over the years, but the society also put a particular emphasis on religiosity in various aspects of their daily practices(Himawan, Bambling, \& Edirippulige, 2017, 2018). As a country, Indonesia holds tight religiosity as a guideline for humanity, reflected in its first and foremost principle of Pancasila (as a nation's fundamental principle): “Ketuhanan Yang Maha Esa” (belief of one supreme being). With six acknowledged religions in Indonesia (Islam, Christian, Catholic, Hindu, Buddhist, and Khong $\mathrm{Hu} \mathrm{Cu}$ ), 99.49 percent claims to hold a religion, where Islam has the most followers (87.18\%), while Christians came second (6.96\%) (Badan Pusat Statistik, 2010). This explains why most actions in Indonesia are based on religious beliefs and, at the same time, also highlight the universality of the manifestation of conservative and pseudo-religious based thinking in the society (Himawan, 20I3). 
Whereas previous studies have demonstrated the role of religiosity in reducing the likelihood of performing reckless behavior, we find the importance of investigating such patterns of reckless behaviors on the cognitive level, beyond the behavioral context. Understanding the cognitive level is deemed to be important because emerging adults have much-improved reasoning capabilities and decision-making skills compared to individuals at younger ages (Reyna \& Farley, 2006); hence, cognitive intervention could be considered in preventing the risk of adulthood reckless behavior.

Religion often underlies the belief system in narrow socialization, where obedience and conformity are the highest values, and deviation is undesirable (Arnett, 1995). That said, there is a possibility that individuals with a higher level of religiosity are less likely to engage in performing reckless behavior because of their behavioral compliance to the religious values, rather than due to the understanding of religious values that causes a cognitive shift in their pleasure perception of performing reckless behavior. The objective of the study is to critically evaluate if religious people engage in less reckless behaviors simply because they are not supposed to, or are beyond compliance to rules, to the point where they do not seem to find pleasure in those activities anymore.

Pleasure as a Desired Sensation that Drives Individuals' Action

Pleasure has been known as one of the positive affects and an important part of happiness (Biswas-Diener et al., 2015). Pleasure in its most literate meaning is satisfaction, sensation, an enjoyable feeling, and contentedness; thus pleasure was elaborated as an experience of fulfillment sensation after satisfying a need or desire (Nicklaus, 2016). Horiuchi (2003) defined pleasure as an emotion that is desirable and caused by problem-solving, in addition to the enjoyment of arts or games. Thus, the pleasure here refers to a subjective desired enjoyable sensation of fulfillment or contentedness associated with accomplishment that may act as a motive or outcome. The term subjective is as the enjoyable sensation may vary among people.

\section{Sensation Seeking as a Motivation of Reckless Behavior Among Emerging Adults}

Acknowledging identity exploration as one of the characteristics of emerging adults (Arnett, 1995), reckless behaviors among individuals at this developmental stage have been studied in many works of literature. As parts of exploring identity, reckless behaviors include 
unprotected sex, substance use, or reckless driving behaviors (speeding or driving while intoxicated) (Arnett, 2000). These behaviors seem to be done in a desire to try many things before settling down. A desire for new experiences and intense feelings were also found to be consistently related to the behaviors (Arnett 2000). At these ages, they are less constrained as they are less likely to be monitored by parents and less committed to taking a role as adults.

Arnett (1995) stated sensation seeking as one of the developmental reasons for these reckless behaviors as they give intense experiences. Adolescents commit reckless behavior merely for the sensation-seeking experience with potentially negative consequences, which may include serious personal injury, unwanted pregnancy, or arrest and conviction by the legal system. With the illustrated damages of reckless behaviors (Arnett, 1992), it is now a concerning issue to prevent and intervene with such actions.

\section{The Role of Religiosity in Reducing Reckless Behavior}

There are a few factors that influence the pleasurable experience. Whereas cultural factors were found to shape what people view as good, moral, and virtuous (Rozin, 2003; Shweder, 2003), the experience of pleasure is found to be influenced by culture (Biswas-Diener et al., 2015). Catania, Abdulcadir, Puppo, Verde, Abdulcadir, and Abdulcadir (2007) resonate the influence of culture on defining pleasurable experience through their finding that culture, as well as social acceptance, can change the perception of pleasure. As individuals are exposed and engaged in a certain culture, the socialization process influence how they construct and experience emotion, including how they define their pleasure (Biswas-Diener, 20I5).

Religion, as a part of a culture, has been found to influence certain behaviors. On drinking behavior, for instance, girls in school societies with more religious parents drink less than boys, but they were found to drink more than boys in less religious society (Bjarnason, Thorlindsson, Sigfusdottir, \& Welch, 2005). In an academic setting, a correlation was found where highly religious students tend to perform well in academics, study better, and to be less involved in reckless behaviors compared to less religious students (Abar, Carter, \& Winsler, 2008). With regards to the view of pre-nuptial sex, strongly religious people have greater pre-marital sex opposition (Cochran\& Beeghley, 199I). Further, even with control 
for age, gender, region, and education of parents, religious adolescents were found to be less likely to commit crime than nonreligious adolescents (Smith \& Faris in Hair, Moore, \& Kuhfeld, 2009).

As risks are evaluated in committing these reckless behaviors (Isen, Means, Patrick, \& Nowicki, 1982), a possibility to accelerate the maturation of self-regulatory competence to intervene in risky decision making is suggested (Steinberg, 2007). Hence, religion could contribute to advancing the self-regulatory competence through its teachings, that may be reflected in the shift of pleasure perception in performing reckless behavior.

\section{Method}

\section{Participants}

A total of 580 participants living in Jakarta and Tangerang regions participated in this study. Participants were achieved through an online survey. The inclusive criteria set for the eligibility of participating were: I) be within 18 - 25 years old, 2) reside in Jakarta or Tangerang regions. Among the obtained data, after performing an initial assessment, I39 data were eliminated due to unmet criteria and having incomplete responses. Thus, this final sample constituted $44 \mathrm{I}$ individuals $\left(M_{\text {age }}=20.69\right.$; $\left.S D=I .7 \mathrm{I}\right)$, of which $37.9 \%$ were males.

\section{Instruments}

We utilized questionnaires as a method of data gathering. Participants' levels of religiosity were measured by The Four Basic Dimensions of Religiousness Scale (4BDRS; Saroglou, 20I I), whereas levels of pleasure perception were measured by Perceived Pleasure in Common Reckless Behavior Scale (PCRBS).

The Four Basic Dimensions of Religiousness Scale (4BDRS; Saroglou, 20II) consisted of I2 items, measuring four sub-dimensions of religiosity, namely namely Believing (i.e. "I feel attached to religion because it helps me to have a purpose in my life"), Bonding (i.e., "Religious rituals, activities or practices make me feel positive emotion"), Belonging (i.e., "Religious rituals, activities or practices make me feel positive emotion"), and Behaving (i.e., "Religion helps me to try to live in a moral way"). This scale has been adapted into the Indonesian language by Vigar, Himawan, and Mutiara (2016). Participants were asked to indicate their responses based on 
7 rating scale $(\mathrm{I}=$ rarely true; $7=$ almost always true $) A$ total score of this scale represents participants' religiosity levels. In this study, the BDRS shows satisfactorily internal stability ( $\alpha$ $=.938)$.

Perceived Pleasure in Common Reckless Behavior Scale (PCRBS) was particularly developed for this study, designed to assess an individual's perceived pleasure in reckless behavior. PCRBS consisted of 37 items, where participants indicated their perceived pleasure on items (such as smoking, forcing someone into any sexual practice, or binge drinking)on a 5-point scale (I $=$ very not pleasurable; 5 = very pleasurable). The items included in this scale were based on I). The adoption of the Reckless Behavior Questionnaire (RSQ; Arnett in Desrichard, Vos, Bouvard, Dantzer \& Paignon, 2008) that has been adjusted to fit contextually to Indonesian settings, and 2). A criminal acts list from Biro Pengendalian Operasi Kepolisian Republik Indonesia [Operational Bureau of the Indonesian National Police] as recorded by Badan Pusat Statistik (2014). The criminal acts were considered fit to be included as they possess reckless behavior qualities, such as legal and physical risks. Prior to being utilized in the main study, we performed a tryout of the initial scale to 49 participants. There were three items added in the final form of PCRBS, as suggested by participants. The Cronbach alpha coefficient of this scale is .864 .

\section{Procedure}

A pack of questionnaires was administered to selected participants, either through an online survey. A participant information sheet was presented on the first page of the survey, containing a general information about the study, including benefits, risks, and confidentiality. Participants were required to click the 'agree' button, indicating their consent to participate before being able to access the questions. The procedure of this study was approved through the author's institutional research mechanism.

Participants also gave demographical data in the space provided, which include age and gender. Upon completion of informed consent and demographical data, participants filled the scales in this order; Perceived Pleasure in Common Reckless Behavior Scale (PCRBS), and The Four Basic Dimensions of Religiousness Scale (4BDRS). PCRBS was rated I-5. Explanations of the meaning of the scales were specified. 


\section{Statistical Analysis}

Multiple regression with entering method was performed to test the influence of religiosity in reducing participants' pleasure perception toward reckless behavior. Gender was entered as a control variable. A Pearson correlation technique was also performed for supplementary analysis. All statistical analyses were done through the SPSS program.

\section{Results}

Correlation between Religiosity and Reckless Behavior

A Pearson correlation was applied to test the correlation between participants' level of religiosity and their frequency of conducting reckless behavior. It was found that those with higher religiosity scores reported less frequency of conducting reckless behavior $(r=.619 ; p$ $=.000)$.

\section{The Contribution of Religiosity to Pleasure Perception toward Reckless Behavior}

Before performing a multiple regression, we tested the correlation between participants' levels of religiosity and their pleasure perception toward reckless behavior. It was found that there exists a significant, negative correlation $(r=-.188 ; p=.000)$, suggesting that the higher religiosity scores participants have, the lower pleasure perception they have toward performing reckless behavior (see Table I).

Table I.

Correlation between Pleasure Perception and Religiosity

$\begin{array}{lllll}2 & 3 & 4 & 5 & 6\end{array}$

Perception of Pleasure in Reckless

Behavior (PCRBS)

Religiosity level (4BDRS)

$-.188 * *$

Believing dimension (4BDRS-subI) $\quad-.172^{* *}$

$\begin{array}{lllll}\text { Belonging dimension (4BDRS-sub3) } & -.175^{* *} & .820 * * & .555^{* *} & .635^{* *}\end{array}$

$\begin{array}{llllll}\text { Behaving dimension (4BDRS-sub4) } & -.16 \mathrm{I}^{* *} & .908^{* *} & .762^{* *} & .735^{* *} & .677^{* *}\end{array}$

$* * p<.0$ l (2-tailed).

Next, we performed a hierarchical regression to test the contribution of religiosity in reducing participants' pleasure perception toward committing reckless behavior. In the first model, we put gender as a controlling variable, whereas in the second model, we put both 
gender and participants' pleasure perception in reckless behavior score (see Table 2). The result showed religiosity level explained $40 \%$ of the variance of an individual's perception of pleasure in reckless behavior $\left(R^{2}=.045 ; F(2,438)=10.214 ; p=.000\right)$. It was found that while gender was not a significant predictor $(\beta=2.715 ; p=.06 \mathrm{I})$, religiosity was significantly predicted participants' perception of pleasure in reckless behavior $(\beta=.69 .97 ; p=.000)$.

Table 2.

Hierarchical Multiple Regression, dependent variable: Pleasure Perception

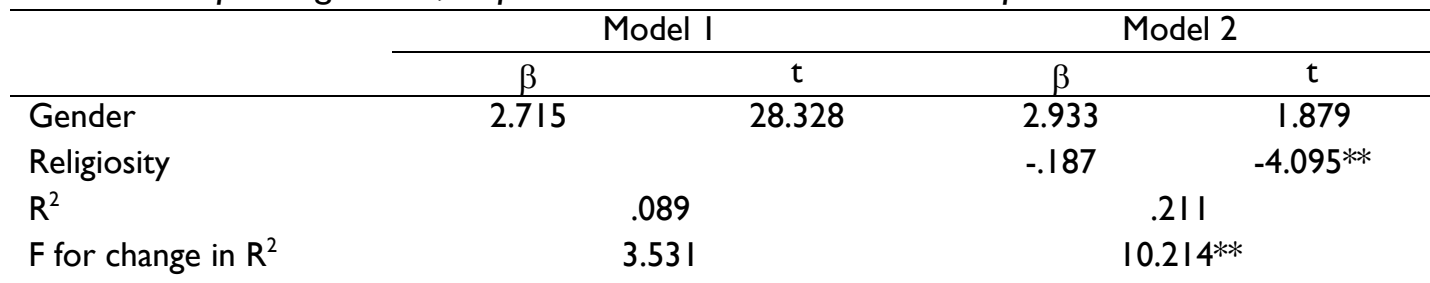

Remarks: $*=$ significant at .05 level; $* *=$ significant at .001 level

\section{Analysis of Supplementary Data}

For further analysis, a Pearson correlation was performed between participants' frequency of committing reckless behavior and their pleasure perception. The finding suggests that individuals who have done more frequent reckless behaviors reported more pleasure perceived $(r=.619 . p=.000)$. This result justifies the fact that reckless behaviors truly gives pleasure sensation.

We also performed gender analysis towards participants' levels of religiosity and their perception of pleasure in reckless behavior. It was found that there is no significant differences between males and females participants with regards to their religiosity level ( $t$ $(439)=-.786 ; p=.433)$ and their perception of pleasure in reckless behavior $(t(324.49)=-$ I.879; $p=.067)$.

\section{Discussion}

The main purpose of this study was to provide empirical findings on whether or not religiosity influences the perception of pleasure in reckless behavior among emerging adults. 
After controlling gender, the result of this study confirms the acceptance of the hypothesis that there is a significant influence of religiosity towards the perception of pleasure in reckless behavior among emerging adults. It was found that religiosity influences perception of pleasure in reckless behavior negatively, where more religious individuals would perceive less pleasure in reckless behavior.

We propose two main arguments with regards to this finding. The first argument is that the findings in this study confirm those of previous studies that religiosity, as a part of socialization or culture, influences the perception of pleasure in reckless behavior (Tsai, Louie, Chen, Uchida, 2007; Biswas-Diener et al., 20I5). Culture is believed to play a part in shaping an individual's perception of good, moral, and virtuous. Justified by Biswas-Diener et al. (2005), not only religion affects whether individuals perceive pleasure, but it also affects how it is perceived. Religions shape individuals' perception and eventually result in less reckless behaviors committed through the clear endorsement of specific affective states (Tsai, Louie, Chen, Uchida, 2007). According to Tsai, Louie, Chen, Uchida (2007) these endorsements are done through various media such as sacred writings, painting, and sculptures (Jesus in the Bible and Buddha in the Lotus Sutra). They are likely to endorse negative affective states on reckless behaviors. Hence, less pleasure is perceived.

The second argument is based on the perspective of the development stages of emerging adults. In stages of faith, emerging adults are usually in synthetic-conventional faith or individuative-reflective faith (Papalia \& Feldman, 20II). The stages involve more abstract thinking that adopts beliefs and commitments to conform to community standards. Adopting beliefs that would contain moral values is related to the influence of believing and behaving dimensions (Saroglou, 20I I), where individuals are shaped into a distinct set of mind. Moral values itself is in a cognitive aspect, which directly shapes perception. In this case, the moral values those related to negative perceptions towards reckless behaviors. Also, individuals adopt beliefs and commitments to conform to community standards, which relates to the belonging dimension. Conforming to community standards may also involve possible shifts of perception towards similar views in the group. Religious groups are likely to be against reckless behaviors. Hence individuals take in similar view conforming to the group. In other words, conformity to the religious group may also come in the form of cognitive shift, rather than only behavioral changes. 
The current study contributes to the explanation of how religiosity reduces individuals' likelihood in performing reckless behavior by suggesting the role of religiosity in shifting individuals' perception toward performing such reckless action. We showed that religiosity influences the way people think and perceive reckless behavior, particularly in terms of the pleasure derived from performing such actions.

We acknowledge a few limitations of the study that future scholars interested in this topic should address. We noted the disproportional of gender representation in our sample group, for which the results might be more representative to woman participants. This occurs as a consequence of utilizing convenience sampling. This study was also carried out in the cross-sectional design, which was not the best design to confirm the causal links between variables, compared to case studies or longitudinal studies. Finally, participants' religious affiliation was not particularly analyzed in this study, which may act as a potential bias in determining the result.

\section{Conclusion}

This study has demonstrated that religiosity, in general, has a significant negative influence on the perception of pleasure in reckless behavior among emerging adults. The credibility is supported by supplementary data findings. This finding confirms the possibility of the religiosity to take a role in shifting individuals' cognitive appraisals, particularly when perceiving reckless behaviors.

For future scholars who are interested in studying this topic in Indonesia, it is recommended to take the information about the individual's religion since Indonesia acknowledges six different religions. Further, it may serve as useful information for further data analysis to collect not only the kind of religion but also other information relating to the religiosity, such as duration of belief, involvement, group pressure, and level of spirituality. Personality may also be assessed in the hope of giving an additional explanation on the perception of pleasure in reckless behavior. Relationship of religiosity and personality could also be explored. Further examination using qualitative method is also encouraged to validate the implications. 
Having found out that religiosity influences perception of pleasure in reckless behavior, it is expected that the outcome of this study could give insights into the practical ground to reduce reckless behavior, particularly among emerging adults. In an attempt to reduce reckless behavior committed, it is worth for counselors or mental health practitioners to consider including religious approach.

\section{References}

Abar, B., Carter, K. L., \& Winsler, A. (2009). The effects of maternal parenting style and religious commitment on self-regulation, academic achievement, and risk behavior among African-American parochial college students. Journal of Adolescence, 32(2), 259-273.

Arnett, J. J. (1992). Reckless behavior in adolescence: A developmental perspective. Developmental review, I2(4), 339-373.

Arnett, J. J. (1998). Risk behavior and family role transitions during the twenties. Journal of youth and adolescence, 27 (3), 30I-320

Arnett, J. J. (2000a). Emerging adulthood: A theory of development from the late teens through the twenties. American psychologist, 55(5), 469.

Arnett, J. J. (2000b). Optimistic bias in adolescent and adult smokers and nonsmokers. Addictive behaviors, 25(4), 625-632.

Badan Pusat Statistik. (2010). Penduduk Menurut Kelompok Umur, Daerah Perkotaan/Perdesaan, dan Jenis Kelamin: Provinsi DKI Jakarta. Retrieved November I2, 20I5, from http://sp20 I0.bps.go.id/index.php/site/tabel?tid=263\&wid=3 I00000000

Badan Pusat Statistik. (20I4). Statistik Kriminal 20/4. Jakarta: Badan Pusat Statistik

Bartlett, J. E. II,Kotrlik, J. W. K. J. W., \& Higgins, C. C. H. C. C. (200I).Organizational research: Determining appropriate sample size in survey research appropriate sample size in survey research. Information technology, learning, and performance journal, 19(I), 43.

Biswas-Diener, R., Linley, P. A., Dovey, H., Maltby, J., Hurling, R., Wilkinson, J., \& Lyubchik, N. (20I5). Pleasure: An Initial Exploration. Journal of Happiness Studies, I6(2), 313332.

Bjarnason, T., Thorlindsson, T., Sigfusdottir, I. D., \& Welch, M. R. (2005). Familial and religious influences on adolescent alcohol use: A multi-level study of students and school communities. Social Forces, 84(I), 375-390.

Bradley, G., \& Wildman, K. (2002). Psychosocial predictors of emerging adults' risk and reckless behaviors. Journal of youth and adolescence, 3I(4), 253-265. 
Caissie, L. T., \& Halpenny, E. A. (2003). Volunteering for nature: Motivations for participating in a biodiversity conservation volunteer program. World Leisure Journal, 45(2), 38-50.

Carver, C. (2003). Pleasure as a sign you can attend to something else: Placing positive feelings within a general model of affect. Cognition \& Emotion, I 7(2), 24I-26I.

Catania, L., Abdulcadir, O., Puppo, V., Verde, J. B., Abdulcadir, J., \& Abdulcadir, D. (2007). Pleasure and orgasm in women with female genital mutilation/cutting (FGM/C). The journal of sexual medicine, 4(6), 1666-1678.

Cochran, J., \& Beeghley, L. (1991). The influence of religion on attitudes toward nonmarital sexuality: A preliminary assessment of reference group therapy. Journal for the Scientific Study of Religion, 30(I), 45-62.

Crow, S. R., \& Small, R. V. (20II). Developing the Motivation within: Using Praise and Rewards Effectively. School Library Monthly, 27(5), 5-7

Dekker, P., \& Halman, L. (2003). Volunteering and values. In The values of volunteering (PP. II7). Springer US.

Desrichard, O., Vos, P., Bouvard, M., Dantzer, C. \& Paignon, A. (2008). The French version of the Arnett Inventory of Sensation Seeking: Internal and predictive validity. Personality and Individual Differences, 44(8), 1673-1683

Hair, E. C., Moore, K. A., Kuhfeld, M., \& Sidorowicz, K. (2009). Parent and family religiosity during adolescence: The influence on risky behavior during the transition to adulthood. Washington, DC: Child Trends.

Himawan, K. K. (20I3). Magical thinking in Jakarta: What makes you believe what you believe. Asia Pacific Journal of Counselling and Psychotherapy, 5(I), 3-9.

Himawan, K. K., Bambling, M., \& Edirippulige, S. (2017). Modernization and singlehood in Indonesia: Psychological and social impacts. Kasetsart Journal of Social Sciences. (In press). doi:10.1016/j.kjss.2017.09.008

Himawan, K. K., Bambling, M., \& Edirippulige, S. (2018). Singleness, religiosity, and the implication for counselors: The Indonesian case. Europe's Journal of Psychology, 14(2), 485-497. doi:10.5964/ejop.vI4i2. 1530

Horiuchi, K. (2003). A new perspective on hedonic consumption. European Advances in Consumer Research, 6, 265-269.

Isen, A. M., Means, B., Patrick, R., \& Nowicki, G. (1982). Some factors influencing decision making strategy and risk-taking. Affect and cognition: The 17th annual Carnegie Mellon Symposium on Cognition (pp. 24I-26I). Hillsdale, NJ: Erlbaum

Morfit, M. (198I). Pancasila: The Indonesian state ideology according to the new order government. Asian Survey, 838-85I.

Nicklaus, S. (2016). The role of food experiences during early childhood in food pleasure learning. Appetite, 104(I), 3-9. 
Papalia, D.E. \& Feldman, R.D. (20II). Human Development (10 ${ }^{\text {th }}$ ed.). New York: McGrawHill Companies

Rahadian, L. (2014, November 27). Penularan HIV dari suami makin meningkat. [Article]. Retrieved from http://www.cnnindonesia.com/nasional/2014II27/53/24-2014272/penularan-hiv-dari-suami-makin-meningkat/

Reyna, V. F., \& Farley, F. (2006). Risk and rationality in adolescent decision making: Implications for theory, practice, and public policy. Psychological science in the public interest, 7(I), I-44.

Rozin, P. (2003). Five potential principles for understanding cultural differences in relation to individual differences. Journal of Research in Personality, 37, 273-283.

Rucci, L., van Allen, Z. M., \&Zelenski, I. M. (20I8). Pro-social personality traits, helping behavior, and ego-depletion: Is helping really easier for the dispositionally prosocial?. Personality and Individual Differences, I20, 32-39.

Saroglou, V. (20II). Believing, Bonding, Behaving, and Belonging The Big Four Religious Dimensions and Cultural Variation. Journal of Cross-Cultural Psychology, 42(8), I3201340.

Shweder, R. A. (2003). Why do men barbeque? Recipes for cultural psychology. Cambridge, MA: Harvard University Press.

Steinberg, L. (2007). Risk taking in adolescence: New perspectives from brain and behavioral science. Current directions in psychological science, I6(2), 55-59.

Tsai, J. L. (2007). Ideal affect: Cultural causes and behavioral consequences. Perspectives on Psychological Science, 2(3), 242-259.

Tsai, J. L., Miao, F. F., \& Seppala, E. (2007). Good feelings in Christianity and Buddhism: Religious differences in ideal affect. Personality and Social Psychology Bulletin, 33(3), 409421 .

Tsai, J. L., Louie, J. Y., Chen, E. E., \& Uchida, Y. (2007). Learning what feelings to desire: Socialization of ideal affect through children's storybooks. Personality and Social Psychology Bulletin, 33(I), 17-30.

Vigar, L. S., Himawan, K. K., \& Mutiara, E. (2016). Hubungan antara spiritualitas dan religiositas dengan illusion of control pada emerging adults. Mindset, 7(I), I-I5.

Wahid, S.A. (2015, March 14). Ikut balap liar ribuan remaja diamankan Polres Cirebon. Retrieved from http://jabar.metrotvnews.com/read/2015/03/14/37/077/ikut-balapliar-ribuan-remaja-diamankan-polres-cirebon

Yusuf, Y. (20I5, June 14). Bongkar judi balapan liar di Jakarta Barat, 47 pemuda diciduk. Retrieved from http://metro.sindonews.com/read/I012526/170/bongkar-judi-balapanliar-di-jakarta-barat-47-pemuda-diciduk-|434275856Appendix (optional) 
